\title{
REKAYASA PENGELOLAAN SANITASI AIR LIMBAH DOMESTIK TERPADU BERBASIS IPAL KOMUNAL DI KAMPUNG SELUMIT PANTAI KOTA TARAKAN
}

\author{
Denny Indrawanto ${ }^{1}$, A.Tutut Subadyo ${ }^{2}$, Herry Budiyanto ${ }^{2}$ \\ ${ }^{1}$ Mahasiswa Program Magister Arsitektur,Program Pascasarjana Universitas Merdeka Malang \\ ${ }^{2}$ Dosen Program Magister Arsitektur, Program Pascasarjana Universitas Merdeka Malang
}

\begin{abstract}
ABSTRAK
Permukiman Kampung Kelurahan Selumit Pantai (KP-KSP) merupakan perkampungan di Kota Tarakan di pesisir pantai yang berkembang tidak tertata, tidak terkendali, padat penduduk, dan rawan sanitasi. Permasalahannya adalah: (1) rendahnya kesadaran masyarakat berperilaku bersih dan sehat, (2) ketidakberdayaan masyarakat didalam pemenuhan rumah sehat dan layak huni, (3) sanitasi yang buruk dan ketidakteraturan bangunan berkepadatan tinggi, dan (4) keterbatasan prasarana dan sarana lingkungan yang layak. Penelitian berbentuk explanatory research ini bertujuan untuk: (1) mengalisis kinerja sistem sanitasi lingkungan, (2) mengalisis aspek yang berpengaruh pada pemenuhan sanitasi yang layak, dan (3) memformulasikan konsep IPAL Komunal. Metode penelitian yang di gunakan adalah deskriptif kualitatif. Hasil penelitian menunjukkan bahwa kondisi sarana dan prasarana KP-KSP yang minim dan kualitasnya rendah, serta modal sosial warganya belum dioptimalisasi, maka optimalisasi terhadap potensi tersebut dapat menjadi dasar perekayasaan pengelolaan dan pengolahan IPAL Komunal. Sistem aerobik untuk rekayasan IPAL komunal dipilih sebagai teknologi penyelesaian masalah sanitasi khususnya dan peningkatan kualitas lingkungan pada kawasan KP-KSP Kota Tarakan, karena merupakan teknologi ramah lingkungan yang mudah diadopsi oleh masyarakt setempat. Implementasi pengelolaan dan pengolahan sistem IPAL Komunal dengan konsep teknologi Anaerobic Baffled Reactor, perlu dilakukan paralel dengan program pemberdayan masyarakatnya untuk sadar dan peduli lingkungan yang sehat serta huniannya yang layak.
\end{abstract}

Kata-kata kunci : Kampung Selumit Pantai, Pesisir, IPAL Komunal

\begin{abstract}
Settlement Kampung Selumit Pantai Village (KP-KSP) is a village in the city of Tarakan on the coast that develops disorganized, uncontrolled, densely populated, and prone to sanitation. The problems are: (1) low awareness of people behaving clean and healthy, (2) community empowerment in fulfilling healthy and livable homes, (3) poor sanitation and irregularity in high density buildings, and (4) limited infrastructure and proper environmental facilities. This research in the form of explanatory research aims to: (1) analyze the performance of environmental sanitation systems, (2) analyze aspects that affect the fulfillment of proper sanitation, and (3) formulate the concept of Communal WWTP. The research method used is descriptive qualitative. The results showed that the condition of the facilities and infrastructure of the KP-KSP which was minimal and of low quality, and the social capital of its citizens had not been optimized, the optimization of the potential could be the basis for the management and processing of Communal WWTP. The aerobic system for the communal WWTP foundation was chosen as a technology for resolving sanitation problems in particular and improving the quality of the environment in the KP-KSP area of Tarakan City, because it is an environmentally friendly technology that is easily adopted by the local community. The implementation of management and processing of Communal WWTP systems with the concept of Anaerobic Baffled Reactor technology, needs to be done in parallel with the community empowerment program to be aware and care about a healthy environment and proper housing.
\end{abstract}

Keywords: Selumit Pantai Village, Coastal, Communal WWTP 


\section{PENDAHULUAN}

Hasil riset yang dilakukan UNDP pada tahun 2006, menyatakan bahwa setiap menit kurang lebih 3 anak dapat kehilangan nyawanya, disebabkan oleh penyakit yang berhubungan dengan sanitasi yang buruk (Raude et al, 2009), dan cemaran sungai pada air limbah masyarakat (Ismulyanto, 2010) disamping tingginya tingkat pencemaran udara (Cahyani et al, 2019). Di negara-negara berkembang, sekitar 90 anak per 15 menit atau sekitar 6 (enam) anak per detik meningal dunia akibat pelayanan air yang buruk dan sanitasi yang tidak memadai (IMF \& Bank Dunia 2003). Bahkan di China, India dan Indonesia angka kematian balita mencapai dua kali angka tersebut (WEHAB 2002). Pernyataan tersebut menegaskan bahwa pada saat ini, keterlambatan pembangunan dibidang sanitasi merupakan sumber berbagai permasalahan, seperti menurunnya kualitas air tanah dan air permukaan perkotaan, utamanya dipermukiman kumuhnya. Berdasarkan pernyataan Komisi WHO (World Health Organization) mengenai kesehatan dan lingkungan (2001), dinyatakan suatu permukiman atau perumahan yang sehat dan layak huni adalah konsep (sosiologis dan teknis pengelolaan resiko dari perumahan atau permukiman) yang menjadi faktor yang dapat meningkatkan standar kesehatan penghuninya.

Kota Tarakan memiliki sejumlah kampung kumuh, dengan kompleksitas serumit kota-kota besar di Indonesia pada umum-nya. Berdasarkan Surat Keputusan Walikota Nomor.600/HK-XII/304/2017 tentang lokasi perumahan kumuh dan permukiman kumuh, dinyatakan bahwa kawasan Permukiman Kampung di Kelurahan Selumit Pantai (PK-KSP) merupakan kampung dengan tingkat kekumuhan yang sangat tinggi, dimana masyarakat PK-KSP membuang air limbah Grey Water dan Black Water langsung ke laut (cemplung). Berdasarkan Peraturan Menteri Kesehatan Republik Indonesai No 3 Tahun 2014 tentang Sanitasi Total Berbasis Masyarakat (STBM) Pasal 1 ayat 4 berbunyi “ stop buang air besar sembarangan merupakan kondisi perilaku buang air besar sembarangan yang dapat berpotensi untuk penyebaran penyakit " terkait dengan peraturan tersebut dapat dinyatakan bahwa kondisi kawasan PK-KSP belum memenuhi ketentuan tersebut diatas, dimana tampak kualitas hidup masyarakatnya masih rendah. Indikator dari rendahnya kualitas hidup dan kualitas lingkungan pada suatu permukiman adalah ketersediaan prasarana lingkungan (Subadyo, 2018).

Prasarana lingkungan permukiman adalah kelengkapan dasar fisik lingkungan yang memungkinkan lingkungan permukiman dapat berfungsi sebagaimana mestinya. Prasarana utama meliputi jaringan jalan, jaringan air hujan, jaringan pengadaan air bersih, jaringan listrik, telepon, gas dan sebagainya. Sarana lingkungan permukiman adalah fasilitas penunjang yang berfungsi untuk penyelenggaraan dan pengembangan kehidupan ekonomi, sosial dan budaya (Handayani, 2006 \& Subadyo, 2017). Salah satu prasarana lingkungan permukiman yang terkait langsung dengan permasalahan sanitasi adalah: jaringan jalan, jaringan drainase, dan jaringan pengadaan air bersih, dan jaringan pembuangan limbah dan sampah. Oleh sebab itu penting untuk memperbaiki sistem sanitasi di PK-KSP dengan cara mengolah air limbah sebelum dibuang ke badan air sehingga dapat mengurangi bobot pencemaran pada air permukaan. 
Penyediaan akses air minum dan sanitasi yang layak merupakan salah satu indikator kunci yang menjadi acuan dalam mengukur kualitas hidup masyarakat (Silas, 2002). Aspek sanitasi dan kesehatan merupakan unsur kunci untuk menilai keberhasilan pembangunan lingkungan atau dikenal dengan Millennium Development Goals atau MDGs (Andreas, 2001). Dengan kata lain aspek tersebut menjadi indikator yang diperhitungkan dalam MDGs 2019. Dalam dokumen Rencana Pembangunan Jangka Menengah Nasional (RPJMN) tahun 2015-2019, beberapa indikator pembangunan infrastruktur yang relevan dengan upaya meningkatkan kualitas layanan dasar di kawasan permukiman ditujukan untuk mewujudkan universal access untuk 100\% layanan air minum dan 100\% layanan sanitasi yang layak.

Bertolak dari pemahaman di atas, kawasan PK-KSP pada saat ini dan mendatang membutuhkan penanganan, pengelolaan dan pengolahan air limbah (sanitasi) yang memenuhi standar kelayakan dan kesehatan. Bahkan lebih jauh lagi menyangkut sarana dan prasarana lingkungan yang layak, sehingga kawasan PK-KSP dapat dikembangkan sebagai objek wisata yang dapat menimbulkan potensi ekonomi, dan aktivitas produksi lainnya, dengan tetap memperhatikan kaidah pelestarian fungsi lingkungan. Pola kehidupan pada permukiman di kawasan PK-KSP yang tersebar secara memanjang (linier) mengikuti garis pantai, memberi kemudahan bagi warga yang mayoritas nelayan untuk pergi melaut. Sebagaimana diketahui warga kawasan KSP merupakan pelaku utama dalam pembangunan kelautan serta perikanan, yang memiliki budaya paternalistik sehingga mudah untuk dilibatkan dalam peningkatan kualitas lingkungannya dengan cara memaksimalkan modal sosial yang dimiliknya.

Untuk mengoptimalkan sejumlah potensi yang ada pada masyarakat pemukimnya serta kondisi bentang alamnya, maka untuk meningkatkan kualitas lingkungannya dan kualitas sanitasinya perlu dilakukan upaya dengan pendekatan yang dikenal dengan sebutan ekosanita. Ekologi-Sanitasi (ecological sanitation) yang disingkat ekosanita adalah pendekatan ekosistem siklus tertutup (closed loop ecosystem) untuk mengelola limbah kotoran manusia. Sebelum memasuki media tanah, kotoran manusia yang berupa urine dan faeses terlebih dahulu dijadikan pupuk untuk menyuburkan tanaman pangan dan menghasilkan makanan yang akhirnya dikonsumsi oleh manusia. Salah satu sistem ekosanita yang dikembangkan oleh kementerian Pekerjaan Umum dan Perumahan Rakyat (PUPR) bidang Penyehatan Lingkungan dalam bentuk Peraturan Menteri PUPR No.4 tahun 2017 tentang konsep Sistem Pengelolaan Air Limbah Domestik (SPALD), dicoba diimplementasikan rekayasanya sebagai pemecahan masalah dalam buruknya sistem sanitasi di kawasan PK-KSP, yang sekaligus menjadi keutamaan atau urgensi dari penelitian ini.

\section{METODE PENELITIAN}

Metode yang di gunakan adalah deskriptif kualitatif. Penelitian ini dilakukan di kawasan pesisir permukiman padat/kumuh yang terletak di PK-KSP Kecamatan Tarakan Tengah Kota Tarakan Provinsi Kalimantan Utara. Data yang dipergunakan dalam penelitian ini yaitu dilakukan data primer dan sekunder, data primer diperoleh dengan cara pengambilan pengambilan langsung di lapangan melalui observasi, wawancara, pemetaan kawasan, dan pendistribusian kuesioner. Observasi dilakukan untuk mengumpulkan data karakteristik fisik lingkungan terutama yang berhubungan 
dengan kondisi dan ketersediaan sarana dan prasarana lingkungan. Proses observasi dilengkapi dengan alat bantu berupa perekam visual dan buku catatan yang dapat mendokumentasikan seluruh data yang dibutuhkan. Sementara untuk instrumen kuisioner menggunakan jenis kuisioner tertutup dengan pengukur skala Likert yang telah dimodifikasi.

Data Tersebut dihimpun untuk melihat karakteristik biofisik kawasan KSP, termasuk perkembangan dan pembangunan yang ada di tempat tersebut. Teknik pengambilan sampel responden masyarakat PK-KSP di lakukan secara purposive sampling. Wawancara secara mendalam terhadap narasumber di lakukan untuk memahami kondisi sebenarnya. Data sekunder diperoleh melalui institusi terkait yang lain yang kredibel yang mempunyai kapasitas dalam hal sumber data yang dapat dipertanggung jawabkan. Data sekunder tersebut antara lain dikumpulkan dari Dinas Pekerjaan Umum Kota Tarakan, Data Potensi dan Monografi Kelurahan Selumit Pantai, data Tarakan Dalam Angka 2018 dari BPS Kota Tarakan, serta institusi lain yang relevan. Analisis yang digunakan untuk mengulas dan membahan dipergunakan metode analisis deskriptif kualitatif.

\section{PEMBAHASAN}

\section{Lokasi, Guna Lahan, Aksesibilitas, dan Sirkulasi}

Lokasi penelitian merupakan kawasan PK-KSP,di Kecamatan Tarakan Tengah, Kota Tarakan, Provinsi Kalimantan Utara, yang telah mengalami penurunan kualitas lingkungan. Lokasi PKKSP dipilih karena faktor pengelolaan dan faktor penarik ekonomi yang menyebabkan kawasan menjadi kumuh. Argumentasi ini merujuk pandangan Astuti, (2004); \& Handayani, (2006), yang menyatakan bahwa semakin tidak jelas penanggung jawab pengelolaan kawasan dan semakin besar daya tarik ekonomi di sekitar kawasan maka semakin besar kecenderungan terbentuknya kawasan kumuh.
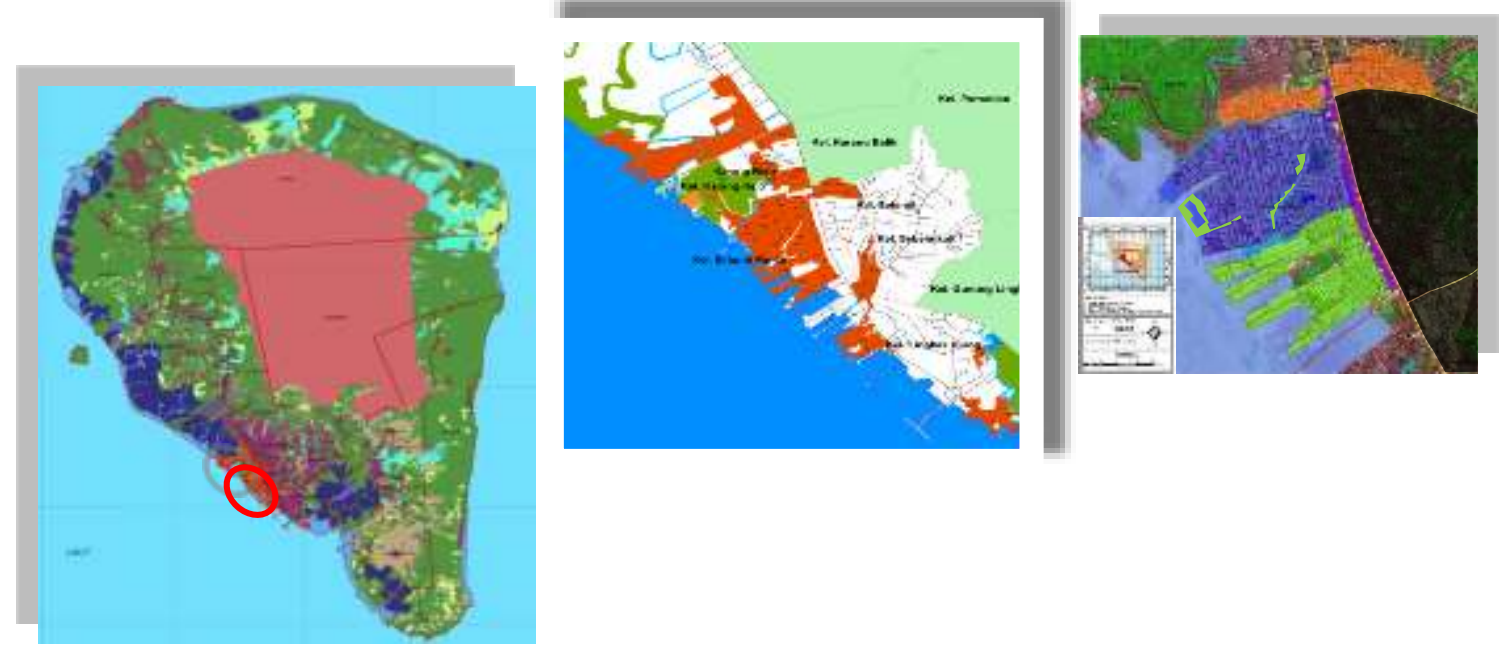

Gambar 1. Gambar 1 Peta Lokasi Kampung Selumit Pantai

Sumber : Dokumentasi Penulis, 2019 
Ketidakjelasan manajemen kawasan terjadi pada lahan-lahan milik negara dimana pengelolaan kawasan tidak terdefinisi dengan jelas atau menjadi otoritas lebih dari satu instansi/institusi (Astuti, 2004; \& Handayani, 2006). Keberadaan faktor-faktor penyebab kekumuhan pada PKKSP yang menjadi lokasi penelitian adalah karena: (1) ketidakjelasan pengelolaan kawasan : berada pada pesisir pantai yang berhimpitan dengan area pelabuhan Tengkayu II dan terlewati sungai Sebengkok , (2) faktor penarik ekonominya: menjadi satu kesatuan dengan kawasan Central Busines District (CBD) Yos Sudarso, dan Pasar Sebengkok, yang menjadi urat nadi perekonomian Kota Tarakan. Kawasan tersebut memiliki karakter yang memperlihatkan kualitas lingkungannya yang rendah : yakni tingkat kepadatan penduduk dan bangunan yang tinggi, sebagian permukiman berada di atas tanah milik negara, minim dan rendahnya kualitas prasarana lingkungan utamanya jaringan air bersih, air limbah, drainase, dan sampah.
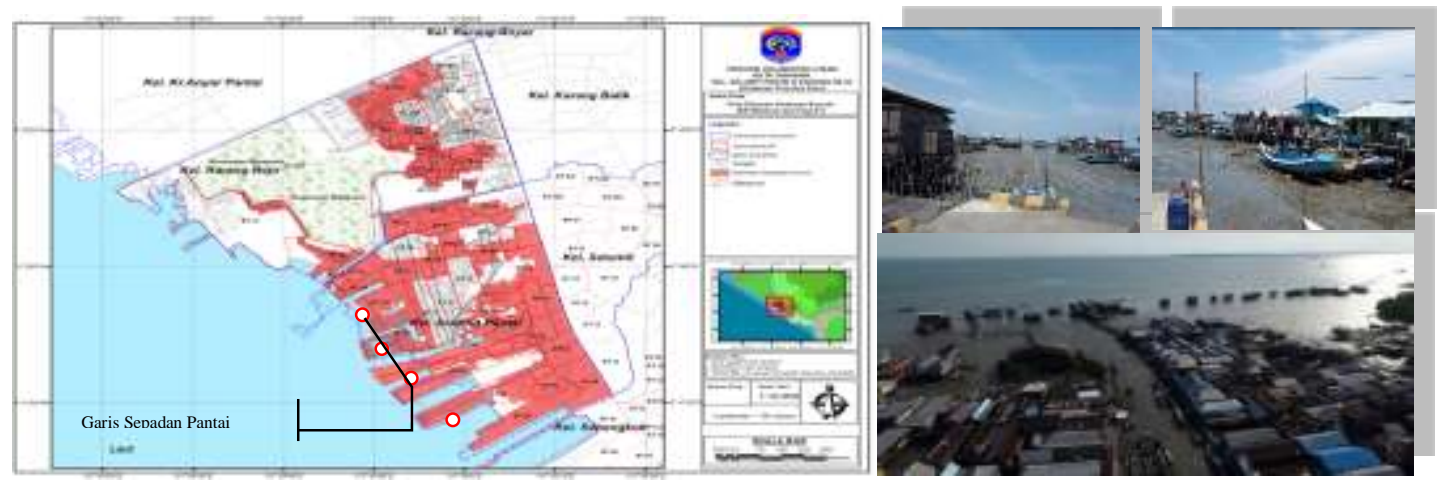

Gambar 2. Kondisi Tapak kawasan PK-KSP yang berada di sepadan pantai Sumber : Dokumentasi Penulis, 2019

Berdasarkan Peraturan Presiden No. 51 tahun 2016, dinyatakan sempadan pantai merupakan daratan sepanjang tepian pantai dan lebar proporsional merupakan bentuk dan kondisi fisik pantai, jarak minimal 100 meter dari titik pasang tertinggi kearah darat dan batas sempadan pantai merupakan ruang sempadan pantai ditetapkan oleh metode dan dilarang pemanfaatan untuk bangunan. Oleh sebab itu, pemanfaatan lahan pada tapak tepian pantai pada PK-KSP sebenarnya tidak sesuai dengan fungsi utama sempadan pantai. Namun kenyataan tersebut telah berlangsung lama, bahkan sebagian area PK-KSP terletak diatas bantara perairan yaitu $88 \%$ dan sisahnya $12 \%$ berada didaratan. Artinya kondisi PK-KSP didominasi daerah dengan topografi dataran rendah/tepi pantai/pesisir. Komponen tanah kawasan pesisir KSP adalah tanah alluvial, yang secara teoritis sebenarnya merupakan ruang penyangga antara ekosistem pantai dan daratan.

Untuk memasuki kawasan PK- KSP terdapat 1775 unit/titik sepanjang dengan panjang jalan 24.320 meter. Menurut Standar Nasional Indonesia Nomor 03-1733-2004 tentang tata cara Perencanaan Lingkungan Perkotaan Jalan Perumahan, bahwa sarana dikatakan baik jika bisa membuat rasa nyaman, aman bagi semua pejalan kaki dan pengguna sepeda gowes maupun sepeda motor. Kondisi dan kualitas jalan yang ada pada kawasan PK- KSP termasuk kategori sempit (rata-rata sekitar $1 \mathrm{~m}$, 
bahkan ada yang lebarnya hanya $45 \mathrm{~cm}$ ). Jaringan jalan yang ada termasuk kategori jalan lingkungan atau antar lingkungan yang menghubungkannya dengan lingkungan sekitarnya atau di dalam lingkungan tersebut. Jalur jalan kecil di dalam kawasan PK-KSP tersebut keberadaannya terhimpit oleh kehadiran bangunan, berkelok, atau kadang meliuk mengikuti rumah-rumah yang terbangun dan bukan sebaliknya,sehingga menghalangi jarak pandang dan menimbulkan kekurang nyamanan pengguna jalan. Hal ini terjadi karena proses pembentukan rumah-rumah yang dibangun secara swadaya oleh masyarakat disesuaikan dengan kemampuan dan kebutuhan, sehingga jalur jalan terbentuk belakangan setelah bangunan rumah-rumah di kawasan PK-KSP didirikan. Jalur jalan tersebut selanjutnya berfungsi sebagai sarana sirkulasi di permukiman tersebut. Akses masuk ke PKKSP dapat dilihat pada gambar di bawah ini.

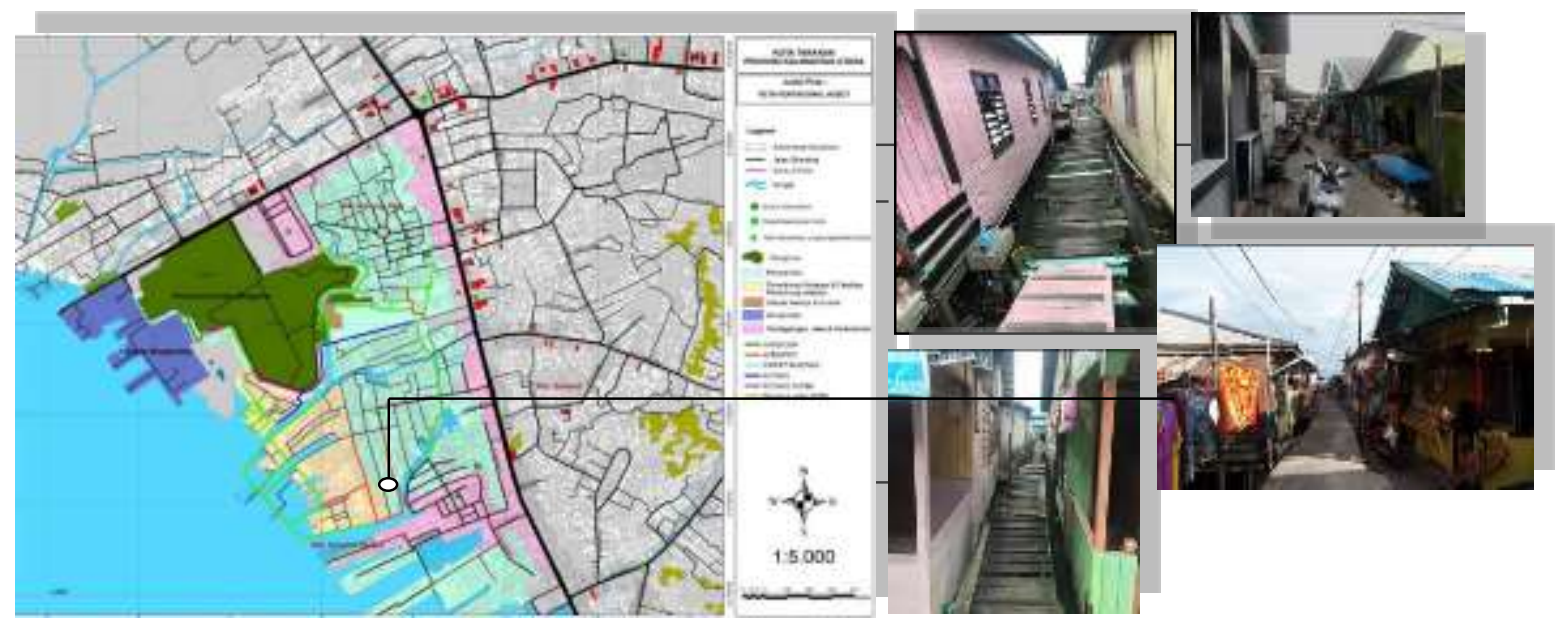

Gambar 3 Sisirkulasi dan Aksesibilitas di kawasan PK-KSP yang terkoneksi dalam bentuk jalur jalan lingkungan

Sumber : Dokumentasi Penulis, 2019

Ketersediaan saluran air hujan meskipun ada namun kondisinya tidak terpelihara sehingga pada saat hujan datang, jalan/gang di permukiman kampung kota menjadi tergenang karena saluran tidak mampu menampung air hujan atau tersumbat sampah yang terserak dan terbawa hanyut air hujan. Demikian halnya dengan ketersediaan jaringan air bersih yang berasal dari PDAM relatif minim. Banyak faktor yang menyebabkan hal ini terjadi, diantaranya selain karena kemampuan ekonomi warga KP-KSP yang terbatas juga terbatasnya lahan sehingga rumahrumah warga seringkali mengabaikan aspek kesehatan lingkungan. Bangunan hunian yang dibangun secara incremental, bersifat swadaya tanpa rencana menjadikan rumah mereka dindingdinding saling berhimpitan. Dengan demikian kondisi kawasan di PK-KSP dapat dinyatakan sebagai kawasan yang tidak nyaman dan tidak sehat sebab tidak di lengkapi dengan ketersediaan prasarana dan sarana lingkungan permukiman yang memadai. Berikut gambaran ruang kampung PK-KSP yang pertumbuhan dan perkembangannya hanya memperhatikan kebutuhan warga tanpa mempertimbangkan aturan tata ruang. 


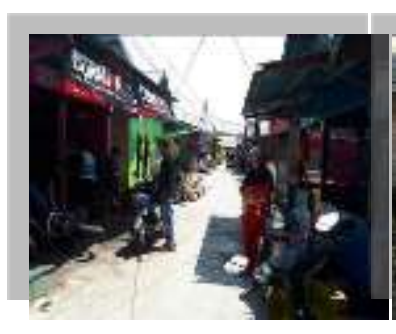

Kondisi Kerapan Rumah

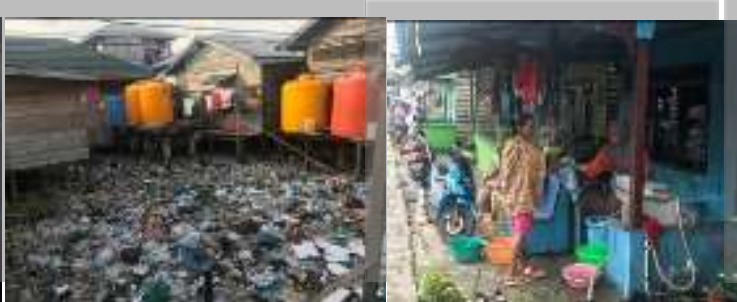

Kondisi Sampah Menumpuk

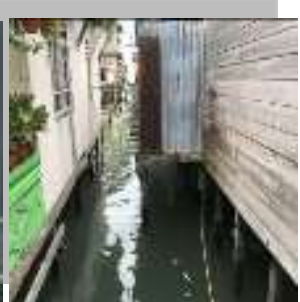

Kondisi tidak memiliki Toilet/Jamban dan Kmr Mandi

Gambar 4. Kondisi Permukiman KSP tidak nyaman dan tidak sehat Sumber : Dokumentasi Penulis, 2019

Tempat sampah di PK-KSP ketersediaanya sangat terbatas, tidak semua rumah tangga memiliki tempat sampah. Untuk beberapa keluarga disediakan satu tempat sampah sehingga tempat sampah tersebut cepat sekali penuh sebelum tukang sampah datang untuk mengangkutnya. Hal tersebut menyebabkan sampah seringkali berhamburan dan menjadikan lingkungan sekitarnya kotor, mengundang lalat dan tidak sehat. Keberadaan tapak PK-KSP yang minim vegetasi menjadikan sebagian besar kawasan ini tidak ternaungi pepohonan sehingga terpapar secara langsung sinar matahari. Dengan kondisi seperti tersebut sudah dapat dipastikan bahwa suhu dalam kawasan PK-KSP tergolong panas $\left(>30^{\circ} \mathrm{C}\right)$ bahkan diduga sudah melampaui batas kenyamanan.

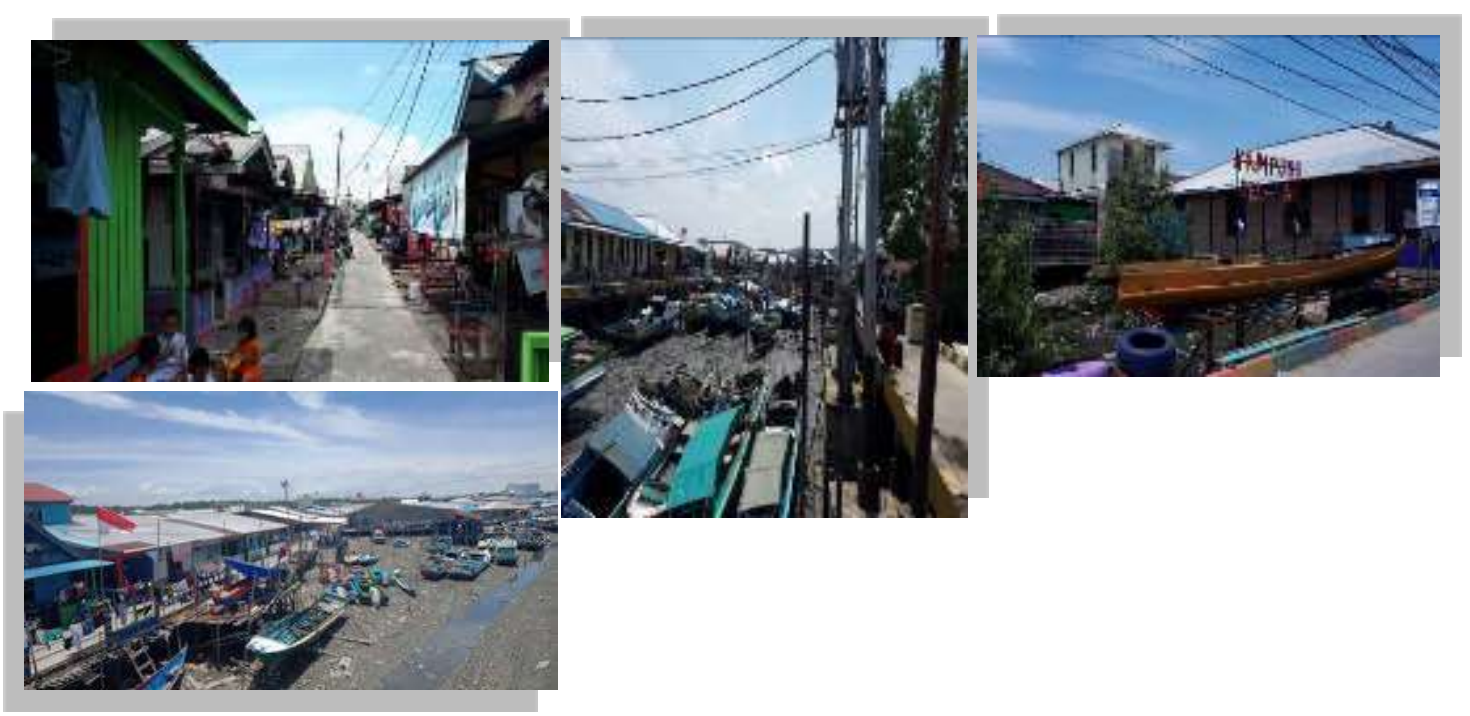

Gambar 5 Kondisi Tapak KSP yang minim vegetasi Sumber : Dokumentasi Penulis, 2019 
Berdasarkan uraian diatas dimana disajikan sejumlah ilustrasi gambar-gambar yang mempertontonkan kondisi sarana dan prasarana lingkungan KP-KSP dapat dinyatakan bahwa sulit kiranya untuk memperbaiki atau meningkatkan kualitas lingkungannya jika tidak ada intervensi para pihak dan pendampingan, pelibatan warga untuk membenahi persepsi dan meningkatkan pengetahuannya tentang kualitas lingkungan dan rumah yang sehat dan layak. Peran tindakan rekayasa terhadap pengelolaan dan pengolahan sanitasi oleh pemerintah adalah sebuah keharusan.

Hasil pengamatan dan penelitian pada KP-KSP dapat dinyatakan bahwa fasilitas dan utilitasnya tidak memenuhi Standar Nasional Indonesia nomor 03-1733-2004, dimana permukiman mempunyai sarana kesehatan minimal, dan ruang terbuka taman minimal seluas 250 meter atau standart $1 \mathrm{~m}$ persegi/penduduk. Dari hasil analisa dan pembahasan tersebut di atas, di tarik kesimpulan bahwa rendahnya tingkat partisipasi dan kesadaran masyarakat KP-KSP terhadap perbaikan dan pembenahan sanitasi menjadi keniscayaan. Meskipun kondisi fisik lingkungan kawasan KP-KSP memiliki sarana dan prasarana yang minim kualitasnya namun dengan hubungan ketetanggaan yang baik warganya mengakibatkan masyarakat merasa nyaman tinggal di permukiman meskipun tentu saja ada faktor lain yang menyebabkan mereka tetap tinggal menetap, seperti jarak dan kedekatan dengan tempat bekerja. Kepadatan bangunan dan kepadatan penduduk pada kawasan KP-KSP memberi kontribusi positif bagi terbentuknya semangat untuk saling membantu dan mementingkat kebutuhan orang lain yang tercermin dalam sikap kegotongroyongan untuk mengerjakan kemanfaatan bersama. Hal ini bisa dimaknai bahwa warga KP-KSP memiliki resiporitas yang cukup kuat sehingga mereka memiliki kepedulian untuk saling membantu. Berikut disajikan gambaran variabel fisik pada kawasan KP-KSP.

Tabel 1 Variabel fisik kawasan KP-KSP Kota Tarakan

\begin{tabular}{|c|c|c|}
\hline Variabel & Indikator & Keterangan \\
\hline \multirow[t]{6}{*}{$\begin{array}{l}\text { Kawasan } \\
\text { permukiman } \\
\text { kampung } \\
\text { Selumit Pantai }\end{array}$} & $\begin{array}{l}\text { Kondisi Bangunan } \\
\text { Gedung }\end{array}$ & $\begin{array}{l}\text { Jumlah bangunan }=2.774 \text { Unit } \\
\text { - Jumlah RTLH }=268 \text { Unit } \\
-1.712 \text { Unit Bangunan tdk teratur } \\
\text { - } 111 \text { Unit/ha tingkat kepadatan } \\
-1.194 \text { Unit Bangunan tidak sesuai }\end{array}$ \\
\hline & $\begin{array}{l}\text { Kondisi Jalan } \\
\text { Lingkungan }\end{array}$ & $\begin{array}{l}\text { Panjang Jalan }=24.320 \mathrm{~m} \\
-15.049 \text { meter tidak sesuai dengan Persyaratan Teknis } \\
-4.077 \text { meter mengalami kerusakan } \\
-5.194 \text { meter sesuai dengan Persyaratan Teknis }\end{array}$ \\
\hline & $\begin{array}{l}\text { Kondisi akses } \\
\text { Air minum }\end{array}$ & $\begin{array}{l}\text { Cakupan Pelayanan Air }=33 \text { unit RT } \\
-2.741 \text { Unit RT tidak dapat Akses } \\
\text { - } 2.518 \text { Unit RT tidak terpenuhi } \\
\text { Kebutuhan Air ( } 60 \text { L/Org/Hari) } \\
\end{array}$ \\
\hline & $\begin{array}{l}\text { Kondisi } \\
\text { Pengolahan } \\
\text { Air Limbah }\end{array}$ & $\begin{array}{l}\text { - } 51 \% \text { - 95\% Sistem pengolahan Air Limbah } \\
\text { tidak Sesuai dengan Standar Teknis } \\
\text { - } 51 \% \text { - 95\% Prasarana dan Sarana } \\
\text { tidak Sesuai dengan Persyaratan Teknis }\end{array}$ \\
\hline & $\begin{array}{l}\text { Kondisi } \\
\text { Pengolahan } \\
\text { Sampah }\end{array}$ & $\begin{array}{l}\text { Cakupan sampah terangkut ke TPS/TPA = } \\
\text { 957 unit rumah tangga } \\
\text { - 16.55 ha kawasan tidak dilengkapi sarana } \\
\text { sesuai persyaratan teknis } \\
\text { - 1.817 unit RT tidak terlayani pengangkutan } \\
\text { ke TPS/TPA } \\
\text {-15.30 ha kawasan tidak terpelihara }\end{array}$ \\
\hline & $\begin{array}{l}\text { Kondisi Proteksi } \\
\text { Kebakaran }\end{array}$ & $\begin{array}{l}\text { Jumlah Bangunan }=3.051 \text { Unit } \\
-8.14 \text { ha tidak memiliki proteksi } \\
11.79 \text { ha tidak memiliki pasokan air } \\
\text { - } 4.667,94 \text { meter jalan tidak dapat dilalui } \\
\text { Mobil pemadam kebakaran }\end{array}$ \\
\hline
\end{tabular}


Sumber : Hasil analisis peneliti, 2019.

Bertolak dari kenyataan tersebut maka dapat diduga bahwa modal sosial warga KP-KSP menjadi bekal utama dalam menerima program rekayasa pengelolaan dan pengolahan IPAL Komunal masyarakat dan di kelola oleh Kelompok Swadaya Masyarakat (KSM), dalam menyelesaiakan masalah sanitasi di lingkungannya. Penyandingan dan pengintegrasian antara modal sosial warga dengan regulasi yang ditetapkan pemerintah pusat (Kementerian PUPR) maupun daerah (Peraturan Daerah Kota Tarakan No 03 tahun 2011 tentang Kesehatan Lingkungan dengan pelaksana Satuan Kerja Dinas Kawasan Permukiman, Perumahan dan Pertanahan Kota Tarakan), dalam pengimplementasian IPAL Komunal pada kawasan KP-KSP menjadi dasar perekayasaannya. Organisasi pelaksana pengolahan air limbah adalah pokja sanitasi dan KSM. Di Kota Tarakan, pokja sanitasi telah terbentuk sejak tahun 2016. Pokja sanitasi melibatkan Organisasi Pelaksana Daerah (OPD) terkait, meliputi Dinas PU, Dinas Permukiman, Dinas Kesehatan, Badan Lingkungan Hidup; unsur masyarakat; dan unsur media.

\section{Implementasi Konsep Pengelolaan dan Pengolahan IPAL Komunal}

Dalam rekayasa pengelolaan dan pengolahan IPAL Komunal di KP-KSP kota Tarakan, pelibatan masyarakat secara intensif melalui pendekatan deliberatif dilaksanakan pada setiap langkah, mulai perencanaan, pelaksanaan, pemeliharaan dan pemantau. Para pihak memiliki peran besar. Keberhasilan implementasi IPAL Komunal di Kampung Selumit Pantai akan sangat tergantung dengan adanya sikap peduli. Sikap peduli ini dapat ditandai dengan asesmen masalah bersama dalam ruang publik,tumbuhnya rasa memiliki dan responsivitas masyarakat tinggi terhadap permasalahan Sanitasi, serta transparansi dan akuntabilitas akses informasi bagi seluruh pihak terkait.

Pada saat perencanaan dilakukan rapat sosialisasi dan rembug kampung beberapa kali pertemuan untuk memutuskan pengajuan proposal secara bermusyawarah untuk mencapai mufakat. Pertemuan awal ini merupakan media membuka pemikiran warga tentang IPAL Komunal, memberi pengertian pentingnya IPAL komunal. Pada tahap ini warga masyarakat menyatakan pendapat, dimana 95\% menyetujui dan hanya 5\% yang tidak setuju. Meskipun yang tidak menyetujui hanya 5\%, namun argumentasi penolakannya menjadi catatan penting yakni: kekhawatiran-kekhawatiran akan bau tidak sedap, kebocoran, dan teknis lainya, ehimgga tetap diperhatikan. Rasa memiliki yang tumbuh dalam jiwa masyarakat serta sifat keterbukaan dan fleksibilitas memudahkan program kegiatan rekayasa IPAL Komunal berjalan baik penerapannya di KP-KSP. Hal ini dapat ditunjukkan adanya transparansi meliputi bidang kejelasan kegiatan, anggaran, mekanisme, dan segala sesuatu terkait kegiatan. Transparansi juga dilengkapi dengan akuntabilitas, yang dibangun berdasarkan pemahaman bahwa fasilitas IPAL Komunal adalah milik bersama, bukan miliki pemerintah (WSP, 2010; Wibisono, 2010). Hasil perekayasan pengelolaan dan pengolahan IPAL Komunal pada kawasan KPKSP Kota Tarakan tersaji pada gambar berikut. 


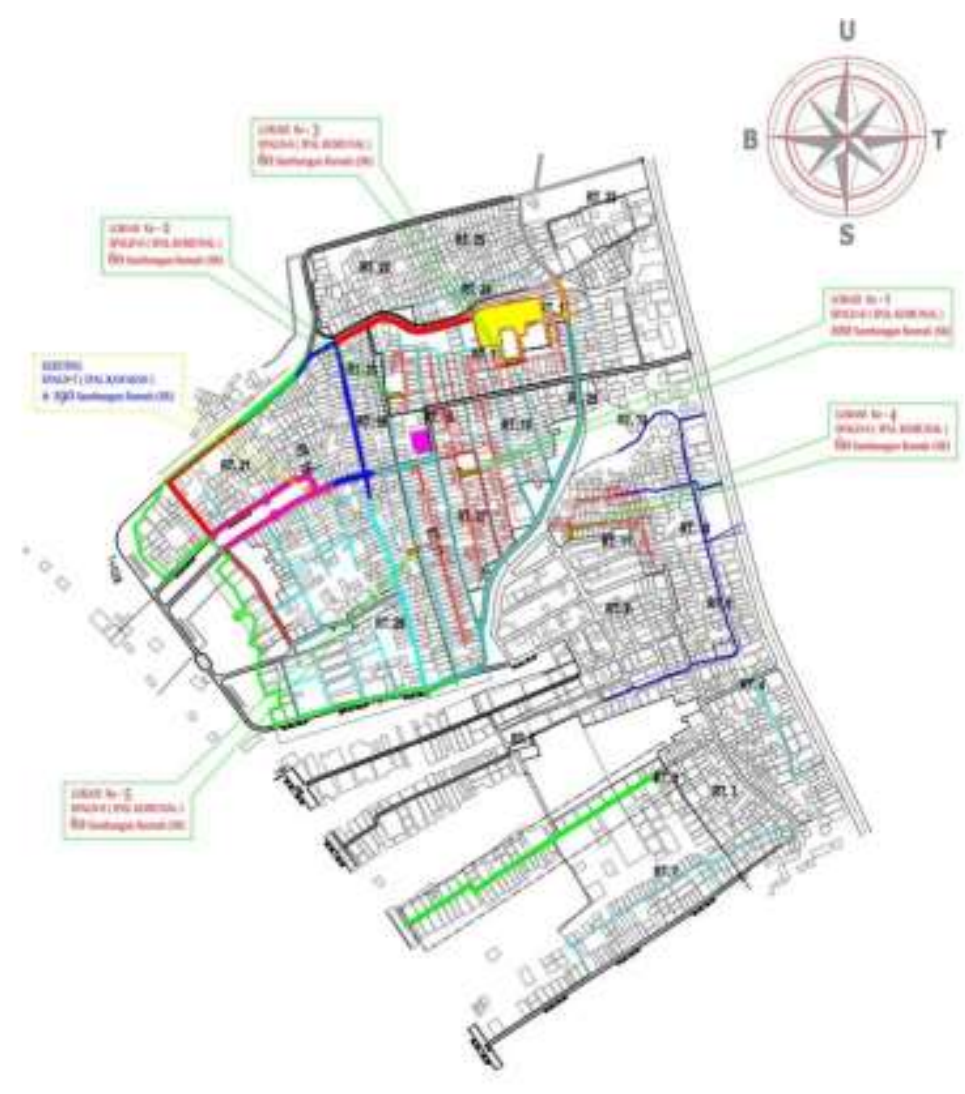

Gambar 6. Implementasi IPAL Komunal di kawasan KP-KSP Kota Tarakan Sumber : Usulan rekayasa Peneliti, 2019.

Pemilihan sistem aerobik pada konstruksi IPAL Komunnal yang diterapkan pada KP-KSP Kota Tarakan, membutuhkan banyak tenaga untuk pembersihan dan perawatannya, sehingga dibutuhkan partisipasi masyarakat yang telah memiliki ikatan kekeluargaan yang kuat, sikap kepedulian masyarakat, untuk mendukung memobilisasi warga, sehingga program berjalan dengan baik dan lancar. Sistem aerobik memiliki sejumlah permasalahan teknologi, sedangkan untuk sistem anaerobik tidak terlalu mempermasalahkan teknologi karena menggunakan mikro-organisme alami untuk penguraiannya (WSP, 2010; Kemen PUPR, 2014, 2017). Dalam hal ini aktivitas pengelolaan IPAL Komunal sebatas menjaga saluran pipa rumah tangga agar selalu tetap lancar. Untuk tetap menjaga kelancaran, maka diadakan pembersihan pipa saluran dalam waktu tertentu. Bila ada kerusakan pipa atau kebocoran, maka ada pembenahan pipa. Hal ini yang dilakukan pengelola IPAL dan masyarakat pemanfaat IPAL dengan sistem anaerobik (Kemen PUPR, 2014). Dengan demikian, kesulitan dalam pengelolaan IPAL Komunal pada KP-KSP Kota Tarakan ada dua aspek yaitu kesulitan teknis teknologi (berkaitan dengan teknis pengoperasian teknologi) dan kesulitan teknis sosial berkaitan dengan hubungan dengan pengguna/pemanfaat IPAL. Teknis sosial yang 
dimaksud adalah komunikasi antara pengelola dengan pemanfaat.

\section{SIMPULAN}

Dari hasil pembahasan tersebut di atas, di tarik kesimpulan :

1. Ketersediaan akses air minum dan sanitasi, serta sarana dan prasarana lingkungan yang layak merupakan salah satu indikator kunci yang menjadi acuan dalam mengukur kualitas hidup masyarakat,

2. Rendahnya tingkat partisipasi, motivasi, dan kesadaran masyarakat KP-KSP terhadap masalah sanitasi, menjadi faktor limitasi yang pemberdayaannya memerlukan pendampingan untuk menata, memelihara, dan mengelola lingkungan permukimannya sehingga menjadi permukiman yang sehat dan layak huni.

3. Keterbatasanya ketersediaan prasarana dan sarana utilitas lingkungan yang masih rendah kualitasnya, dan karakteristik sosial, ekonomi, ekologi dan budaya, yang menyimpan modal sosial, dapat dijadikan dasar dalam perekayasaan pengelolaan dan pengolahan IPAL Komunal.

4. Sistem aerobik untuk rekayasan IPAL komunal dipilih sebagai teknologi penyelesaian masalah sanitasi khususnya dan peningkatan kualitas lingkungan pada kawasan KP-KSP Kota Tarakan, karena merupakan teknologi ramah lingkungan yang mudah diadopsi oleh masyarakat setempat.

\section{REFERENSI}

Andreas, K., Schattauer, and J. Helmut. (2001). Decentralized Approach - Acological Sanitation System for Urban Development. Proccedings of the first Interbational Conference on Ecological Sanitation . 5-8 November 2001. Nanning,China.ASHRAE.(1992). Thermal Environmental Condition for Human Occupancy (ASHRAE Standard 55-56). ASHRAE: Atlanta US.

Anonim. (2018). Profil Kampung Selumit Pantai

Anonim. (2018). Pedoman Teknis Sanitasi Kementerian Pekerjaan Umum dan Perumahan Rakyat. Direktorat Jenderal Cipta Karya Direktorat Pengembangan Penyehatan Lingkungan Permukiman.

Anonim. (2014). Panduan Penyelenggaran Infrastruktur Permukiman. Kementerian Pekerjaan Umum dan Perumahan Rakyat. Direktorat Cipta Karya, Jakarta.

Anonim. (2011). Peraturan Daerah Kota Tarakan No.03 tabun 2011 tentang Kesehatan Lingkungan

Anonim. (2014). Peraturan Menteri Kesehatan Republik Indonesia, No. 3 tabun 2014. Tentang Sanitasi Total Berbasis Masyarakat.

Anonim. (2017). Peraturan Menteri Pekerjaan Umum \& Perumahan Rakyat, No. 4 tabun 2017. Tentang Konsep Pengolahan Air Limbah Domestik.

Anonim. (2017). SK WaliKota. 2017. No, 600/HK-XII/304/2017 tentang Lokasi Perumaban Kumub dan Permukiman Kumub

Anonim. (2004). SNI 03-1733-2004, Tata Cara Perencanan Lingkungan Perumahan

Anonim. (2010). Opsi Sistem \& Teknologi Sanitasi ; Opsi Sanitasi yang Terjangkau untuk. Daerah Spesifik. WSP (Water and Sanitasion Program), 
Denny Indrawanto, A.Tutut Subadyo, Herry Budiyanto, Rekayasa Pengelolaan Sanitasi Air Limbah Domestik Terpadu Berbasis IPAL Komunal di Kampung Selumit Pantai Kota Tarakan

Anonim. (2017). Strategi Sanitasi Kota Tarakan. Badan Perencanaan Pembangunan Daerah (Bappeda) Kota Tarakan.

Anonim. (2017). Kota Tarakan Dalam Angka. Badan Pusat Statistik Kota Tarakan.

Astuti, Dwi. (2004). Manajemen Kawasan Perbatasan Negara

Bianpoen. (1991). Menata Kota dan Permukiman Buruk, JIIS PAU-IS-UI No. 1. Gramedia Pustaka Utama, Jakarta.

Budihardjo, E. (1998). Sejumlah Masalab Pemukiman Kota. PT. Alumni

Cahyani, S.D., Poerwoningsih, D., Wahjutami, E.L. (2019). Konsep Hunian Adaptof sebagai Upaya Penangan Rumah Tinggal Tidak Layak Huni terhadap Resistensi Penyakit Infeksi. MINTAKAT Jurnal Arsitektur. Vol 20, No 2, 79-91.

Handayani, S. (2006). Sikap dan Perilaku Publik Kawasan Kumub Permukiman Kampung Kota di Bandung. Penelitian Fundamental Dikti.

Wibisono, P. Sukowati. (2010). Pengelolaan IPAL Komunal Melalui StrukturKelembagaan Masyarakat Sebagai Bentuk Pengawasan dan Pengendalian Bapedalda Jawa Timur dalam Upaya Pelestarian Fasilitas Penting Bidang Sanitasi, Penelitian Hibah Bersaing,

Laurie, M. (1986). Pengantar kepada Arsitektur Pertamanan. Bandung: Intermatra.

Silas, Johan. 1999. Permukiman Liar Di Perkotaan. Surabaya.

Subadyo, A.T., Poerwoningsih, D. (2017). Design of Integrated Infrastucture Development in Poncokusumo Agropolitan Region Malang Indonesia. Ecology, Environment and Conservation Journal. Vol. 23. No 1. 2017 (63-70).

Subadyo, A.T. (2018). Arsitektur Perdesaan. Makalah dipresentasikan pada Lokakarya Ikatan Arsitek Indonesia (IAI) Cabang Malang.

Subadyo, A.T. et al. (2019). Implementation Analysis of Green City Concept Malang- Indonesia. Journal International Review for Spatial Planning and Sustainable Development. Vol 7. No 2 (2019) $(36-52)$.

Wibisono, G. P., Sukowati. (2010). Pengelolaan IPAL Komunal Melalui Struktur Kelembagaan Masyarakat Sebagai Bentuk. Pengawasan dan Pengendalian Bapedalda Jawa Timur dalam Upaya Pelestarian Fasilitas Penting Bidang Sanitasi, Penelitian Hibah Bersaing. 